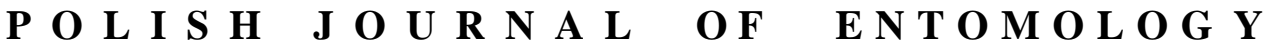

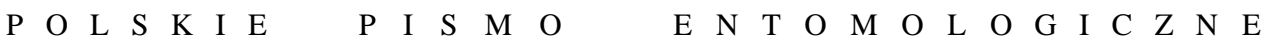

VOL. 83: 5-21

Lublin

31 March 2014

DOI: $10.2478 /$ pjen-2014-0002

\section{Fungus moths (Lepidoptera, Tineidae) of the Białowieża Forest}

\author{
TOMASZ JAWORSKI ${ }^{1}$, JACEK HILSZCZAŃSKI ${ }^{1}$, RADOSŁAW PLEWA ${ }^{1}$, \\ ANDRZEJ SZCZEPKOWSKI ${ }^{2}$ \\ ${ }^{1}$ Department of Forest Protection, Forest Research Institute, Sękocin Stary, Braci Leśnej 3, \\ 05-090 Raszyn, Poland, e-mails: t.jaworski@ibles.waw.pl; j.hilszczanski@ibles.waw.pl; \\ r.plewa@ibles.waw.pl \\ ${ }^{2}$ Department of Forest Protection and Ecology, Faculty of Forestry, Warsaw University \\ of Life Sciences, Nowoursynowska 159, 02-776 Warsaw, Poland, \\ e-mail: andrzej_szczepkowski@sggw.pl
}

\begin{abstract}
New records for twenty species of saproxylic tineid moths (Lepidoptera, Tineidae) from the Białowieża Forest (NE Poland) are presented. Most species were recorded on the basis of laboratory breeding of the adult moths from the sporocarps of wood-decaying fungi inhabited by the larvae. Some species were captured using barrier traps or were collected at light. One species, Dryadaula irinae (SAVENKOV, 1989), is recorded for the first time from Poland and three others, Nemaxera betulinella (PAYKULL, 1785), Nemapogon fungivorella (BENANDER, 1939) and Elatobia fuliginosella LIENIG \& ZELLER, 1846, are recognized as new for the fauna of the Białowieza Forest. The current distribution in Poland of each species is briefly discussed, and some remarks on its biology are given.
\end{abstract}

KEY WORDS: faunistic records, microlepidoptera, saproxylic insects, bracket fungi, wood inhabiting fungi, polypores, old-growth forest.

\section{INTRODUCTION}

The family Tineidae is represented in Poland by more than 50 species in 26 genera. Adults are small to medium-sized moths, usually with cryptic wing colouration. They rest with the wings raised 'tent-like' over the body and run rather than fly when alarmed. Compared to other groups of Microlepidoptera, tineids are distinguished by the unusual biology of their larvae, which are adapted to feed on a variety of materials, including stored food products 
(Nemapogoninae), wool, feather and skin (Tineinae), lichens (some Meessiinae), woodinfesting fungi and decaying wood (Nemapogoninae and Scardiinae). The detailed characteristics of the family were presented by HANNEMANN (1977) and ROBINSON (2009).

Despite the recording in recent years of a number of tineid species new to the fauna of Poland (ŠUMPICH et al. 2011, JAWORSKI et al. 2012, X. DOBRZAŃSKI pers. comm.), knowledge concerning this family is still rather scanty. This is mainly because most tineids lead a very concealed way of life, both as larva and imago, and very few entomologists study them. So far only a few papers have been published on this family of Microlepidoptera in Poland (e.g. ŚLIWIŃSKI 1963, 1969, BUSZKO 1992, 1996).

The principle method of collecting tineids is to rear adult moths from the larvae. For saproxylic species, i.e. dependent on the wood of dead or dying trees or on wood-inhabiting fungi (SPEIGHT 1989), the best results are obtained by collecting the sporocarps of wooddecomposing fungi inhabited by the larvae. As the larvae often live gregariously, a number of specimens can frequently be reared from an individual host fungus. The presence of a larva in the fungus is indicated by granules of frass emerging from the sporocarp. The frass is usually connected with threads of silk.

Old-growth forests are of particular interest when studying saproxylic tineids since they are both rich in number and diverse in species of bracket fungi. In Poland one of the largest and best preserved areas of this type is indisputably the Białowieża Forest (hereafter referred to as BF). It is considered a particularly valuable refuge for many species of fungi, including hundreds of arboreal species (BUJAKIEWICZ 2003, BUJAKIEWICZ \& KUJAWA 2010, SZCZEPKOWSKI et al. 2011). So far no studies have been conducted in this area devoted exclusively to the tineids, although a list of Tineidae of the BF, including 12 saproxylic species, was given by BuszKo (2001).

\section{Acknowledgments}

Very many thanks are due to Dr Mark Shaw (National Museums of Scotland, Edinburgh, UK) for his valuable comments and for improving the manuscript. We also thank Dr Reinhard Gaedike (Bonn, Germany), who confirmed the identification of $D$. irinae. The research was financed by the Ministry of Science and Higher Education under grant No. N N309 101839.

\section{MATERIALS AND METHODS}

The material was collected in 2011-2013 in various locations of the BF. Most of the specimens were collected by rearing the adult moths from the sporocarps of wooddecomposing fungi and decaying wood inhabited by the larvae. Some specimens were 
collected at light or by the use of barrier traps installed on tree trunks (for detailed information about methods, see JAWORSKI et al. 2012). The fungi were identified by the last-mentioned author, and the nomenclature follows the Index Fungorum (2013). The taxonomy and nomenclature of Tineidae follows BUSZKO \& NOWACKI (2000). UTM coordinates, the name of the nature reserve or the nearest village, and the forest compartment number are given for each record. The specimens are deposited in the collection of the Forest Research Institute, Sękocin Stary, Poland.

\section{SYSTEMATICS}

\section{Myrmecozelinae \\ Haplotinea insectella (FABRICIUS, 1794)}

UTM: FD73, Nieznanowo reserve, compartment 488C: 1 male, 25 VII 2011, collected with barrier trap;

UTM: FD73, Starzyna reserve, comp. 698C and 730A: 1 male and 2 females, 25 VII 2011, collected with barrier traps.

The species is known from almost the whole of Poland (BUSZKO \& NOWACKI 2000) and was recently also recorded in BF (ŠUMPICH et al. 2011). It is found both in natural environments as well as indoors. The larvae feed on various materials, including stored food products, grain and wood-inhabiting fungi (BENGTSSON et al. 2008).

\section{Meessiinae}

\section{Stenoptinea cyaneimarmorella (MILLIÈRE, 1854)}

UTM: FD85, Gruszki, comp. 80C: 1 female, 15 VI 2013, collected at light;

UTM: FD83, Podcerkwa reserve, comp. 577A: 1 male, 4 VII 2013, collected at light.

In Poland the species is known from only a few localities, including BF (BUSZKo \& NOWACKI 2000, BUSZKO 2001). Recently it was recorded from north-eastern and western parts of the country (JAWORSKI et al. 2011). Little is known about the biology but larvae are believed to feed on various lichens (BENGTSSON et al. 2008). The adults are sometimes attracted to light.

\section{Agnathosia mendicella (DENIS \& SCHIFFERMÜLLER, 1775)}

(Fig. 1)

UTM: FD73, Nieznanowo reserve, comp. 488C: 1 female, 6 VI 2011, collected at light, 1 female, ex larva, 14 V 2011, 1 female, ex larva, 7 VI 2011, reared from Fomitopsis rosea (ALB. \& SchweIN.) P. Karst. on Norway spruce Picea abies (L.) H. KARST; 


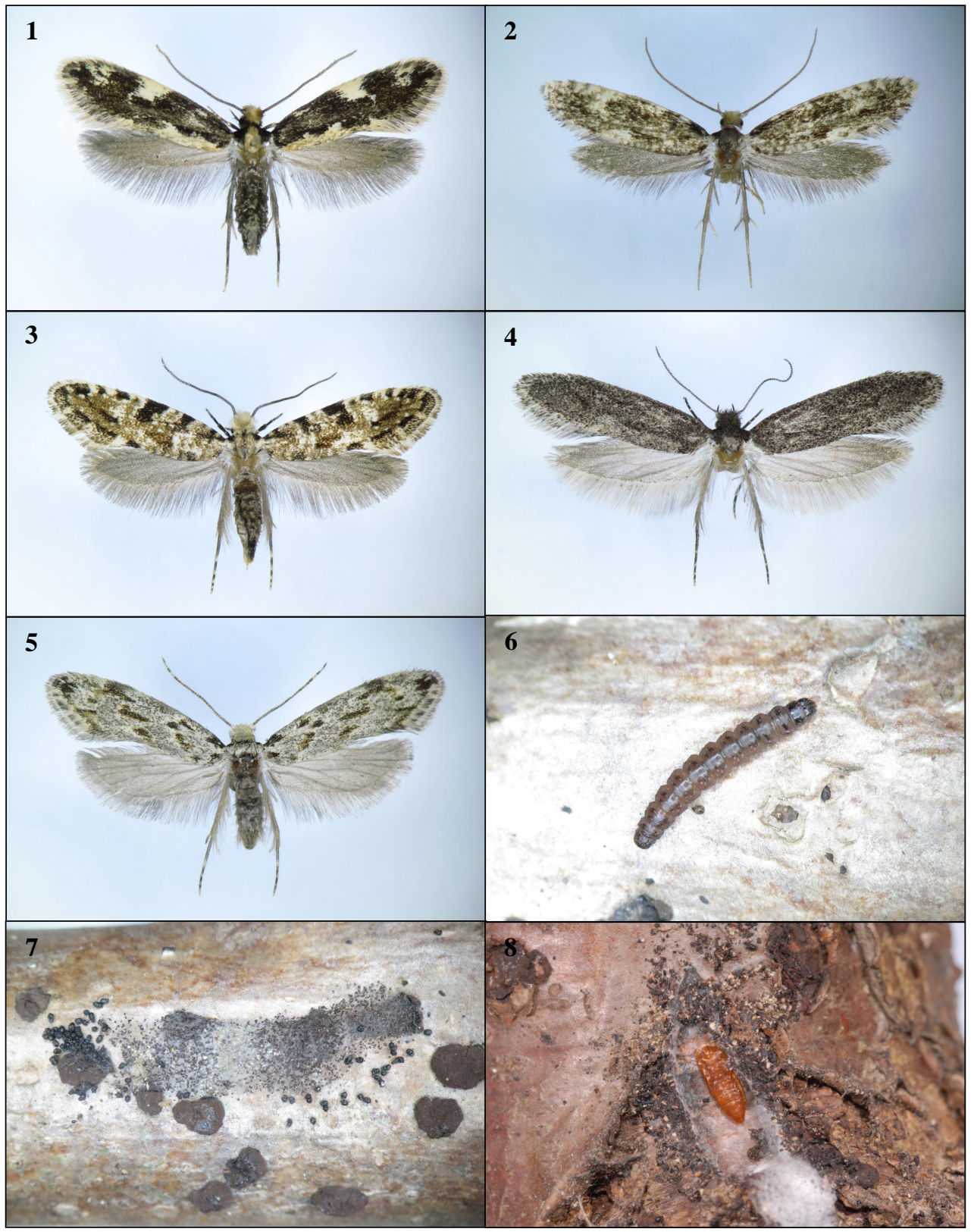

Figs 1-8. 1 - Agnathosia mendicella, female, wingspan 12 mm; 2 - Nemapogon wolffiella, male, wingspan $13 \mathrm{~mm} ; \mathbf{3}$ - Nemapogon fungivorella, female, wingspan $13 \mathrm{~mm} ; \mathbf{4}$ - Elatobia fuliginosella, female, wingspan $22 \mathrm{~mm} ; 5$ - Dryadaula irinae, male, wingspan $13 \mathrm{~mm} ; \mathbf{6}$ - Larva of Dryadaula irinae, length $10 \mathrm{~mm} ; 7$ - Dryadaula irinae - larval shelter; 8 - Dryadaula irinae - pupal case. 
UTM: FD74, Sacharewo, comp. 413B: 1 male, 12 VI 2012, collected at light;

UTM: FD73, Łozice, comp. 569D: 1 male, 11 VI 2012, collected at light;

UTM: FD94, Wysokie Bagno reserve, comp. 477B: 1 male, ex larva, 26 IV 2012, reared from F. rosea on Norway spruce P. abies;

UTM: FD83, Podcerkwy, comp. 523C: 8 males and 13 females, ex larvae, 6 V-18 VI 2012, reared from $F$. rosea on Norway spruce P. abies;

UTM: FD85, Narewka, comp. 186D: 5 males and 6 females, ex larvae, 6 II-22 III 2013, reared from $F$. rosea on Norway spruce P. abies;

UTM: FD74, Lipiny, comp. 272D: 6 males and 11 females, ex larvae, 27 V-3 VII 2013, reared from $F$. rosea on Norway spruce $P$. abies;

UTM: FD94, Wysokie Bagno reserve, comp. 477B: 1 male, 3 VII 2013, collected at light.

The species is distributed in the north-eastern and southern parts of the country (BUSZKO \& NOWACKI 2000) and is rather rarely recorded. Larvae develop on very few species of bracket fungi, with a noticeable preference for Fomitopsis rosea (KOMONEN et al. 2001). In BF the species is quite easy to find in the larval stage. The adult moths are attracted to light.

\section{Scardiinae \\ Montescardia tessulatellus (LIENIG \& ZELLER, 1846)}

UTM: FD83, Przewłoka reserve, comp. 670B: 1 male, ex larva, 29 IV 2011, reared from Piptoporus betulinus (BULL.) P. KARST. on birch Betula pendula RoTH;

UTM: FD94, Wysokie Bagno reserve, comp. 477B: 1 male, ex larva, 18 IV 2012, reared from Fomitopsis rosea (AlB. \& SCHwEIN.) P. KARST. on Norway spruce Picea abies (L.) H. KARST;

UTM: FD73, Łozice, comp. 569D: 1 male, ex larva, 23 IV 2012, 1 male, ex larva 27 IV 2012, reared from Daedalea quercina (L.) PERS. on pedunculate oak Quercus robur L.;

UTM: FD85, Gruszki, comp. 80C: 1 male, ex larva, 21 I 2013, reared from P. betulinus on birch B. pendula;

UTM: FD85, Narewka, comp. 186D: 1 male, ex larva, 22 I 2013, 2 males, ex larvae, 1 II 2013, reared from $P$. betulinus on birch B. pendula;

UTM: FD84, Teremiski, comp. 338A: 1 female, ex larva, 8 III 2013, reared from P. betulinus on birch B. pendula;

UTM: FD74, Lipiny, comp. 271C: 1 male, ex larva, 15 VI 2013, reared from D. quercina on pedunculate oak $Q$. robur.

So far this species was known from the north-east, south-west and south of the country (BUSZKO \& NOWACKI 2000) but a recent record from central Poland (T. JAWORSKI, unpubl. data) may indicate a broader distribution. Larvae feed on a few species of bracket fungi, 
often on Daedalea quercina and Piptoporus betulinus, or in decaying wood (J. BUSZKO, pers. comm.).

\section{Scardia boletella (FABRICIUS, 1794)}

UTM: FD73, Starzyna reserve, comp. 698B, 698C and 730A: 5 females, 25 VII 2011, collected with use of barrier trap;

UTM: FD73, Pogorzelce reserve, comp. 252B: 2 females, ex larvae, 14 VI 2012, 1 female, ex larva, 22 VI 2012, reared from Fomes fomentarius (L.) FR. on pedunculate oak Quercus robur L.;

UTM: FD94, Wysokie Bagno reserve, comp. 477B: 1 female, 3 VII 2013, collected at light.

$S$. boletella is a red-listed saproxylic species. The species is known from only a few localities situated in north-eastern and southern Poland and it is found in mature forests with a continuity of dead wood (BUSZKO 2004). The caterpillars develop in decaying wood of broadleaved trees (mainly of beech Fagus sylvatica L. and birch Betula spp.) and in large sporocarps of polypore fungi (e.g. Fomes fomentarius). In BF the species is common and easy to find especially in the larval stage. The adults are sometimes attracted to light.

\section{Morophaga choragella (DENIS \& SCHIFFERMÜLLER, 1775)}

UTM: FD83, Przewłoka reserve, comp. 670B: 1 female, 7 VI 2011, collected at light, 1 female, ex larva, 29 IV 2011, reared from Fomitiporia punctata (PILÁT) MURRILl on hazel Corylus avellana L.;

UTM: FD73, Nieznanowo reserve, comp. 488C: 1 female, 25 VII 2011, 2 females, 6 IX 2011, collected with use of barrier traps, 3 males, 2 females, ex larvae, 29 IV-10 V 2011, reared from $F$. punctata on hazel C. avellana;

UTM: FD73, Starzyna reserve, comp. 698B, 698C and 730A: 3 males and 1 female, 25 VII 2011, 1 female, 6 IX 2011, collected with barrier traps, 1 female, ex larva, 2 V 2011, reared from Ganoderma applanatum (PERs.) PAT. on pedunculate oak Quercus robur L., 5 males and 3 females, ex larvae, 26 IV-26 V 2011, reared from Trametes sp. On birch Betula pendula RoTH;

UTM: FD83, Topiło, comp. 603A: 1 male, ex larva, 26 V 2011, reared from Cerrena unicolor (Bull.) MuRRILl on birch B. pendula;

UTM: FD73, Łozice, comp. 569D: 3 females, ex larvae, 6-9 V 2011, reared from Bjerkandera adusta (WILLD.) P. KARST. on hornbeam Carpinus betulus L., 1 female, ex larva, 8 VI 2012, reared from Fomitiporia robusta (P. KARST.) FIASSON \& NIEMELÄ on pedunculate oak $Q$. robur;

UTM: FD95, Masiewo, comp. 67C: 1 male, ex larva, 25 II 2013, reared from Fomes fomentarius (L.) FR. on black alder Alnus glutinosa GAERTN., 1 male, ex larva, 1 III 2013, reared from G. applanatum on birch B. pendula, 4 males and 2 females, ex larvae, 1-15 II 2013, reared from B. adusta on Norway maple Acer platanoides L.;

UTM: FD85, Narewka, comp. 186D: 1 female, ex larva, 6 II 2013, reared from Phaeolus schweinitzii (Fr.) PAT. on Norway spruce Picea abies (L.) H. KARST.; 
UTM: FD74, Lipiny, comp. 272D: 1 female, ex larva, 11 VI 2013, reared from Heterobasidion parviporum NIEMELÄ \& KORHONEN on Norway spruce $P$. abies.

The species is distributed throughout Poland (BUSZKO \& NOWACKI 2000) and is one of the most common saproxylic tineids. The larvae inhabit a variety of bracket fungi and may also develop in decaying wood. The adults are sometimes confused with those of Montescardia tessulatellus, from which they can be distinguished by their piliform antennae in males, or on the basis of slight differences in wing pattern.

\section{Nemapogoninae}

\section{Triaxomera fulvimitrella (SODOFFSKY, 1830)}

UTM: FD73, Starzyna reserve, comp. 699A and 729A: 1 female, ex larva, 26 V 2011, reared from Fomes fomentarius (L.) Fr. on birch Betula pendula Rотн, 1 female, ex larva, 19 V 2011, reared from Stereum rugosum PERS. on hazel Corylus avellana $\mathrm{L}$.;

UTM: FD85, Pogorzelce reserve, comp. 252B: 1 male, ex larva, 20 IV 2012, reared from F. fomentarius on hazel C. avellana, 1 male and 2 females, ex larvae, 18-23 IV 2012, reared from Mensularia radiata (SOWERBY) LÁZARo IBIZA on hazel C. avellana, 2 males and 1 female, ex larvae, 18-23 IV 2012, reared from Fomitiporia punctata (PILÁT) MURRILL on hazel C. avellana;

UTM: FD85, Gruszki, comp. 80C: 2 males, ex larvae, 8 and 12 II 2013, reared from M. radiata on hazel C. avellana, 1 female, ex larva, 18 III 2013, reared from Phellinus tremulae (BoNDARTSEV) BondarTSEV \& P.N. Borisov on aspen Populus tremula L., 1 male, ex larvae, 19 V 2013, reared from $F$. punctata on hazel C. avellana, 1 female, ex larvae, 27 V 2013, reared from $F$. fomentarius on hornbeam Carpinus betulus L.;

UTM: FD85, Narewka, comp. 186D: 1 male and 2 females, ex larvae, 13-18 II 2013, reared from decaying wood of hornbeam $C$. betulus;

UTM: FD74, Lipiny, comp. 272D: 1 female, ex larva, 31 V 2013, reared from Stereum rugosum Pers. on hazel C. avellana.

The species is known from only a few localities situated in the north and south of Poland (BUSZKO \& NOWACKI 2000). Recently is was recorded from the Biebrza National Park (JAWORSKI et al. 2011) and, as a new species for this region, from BF (ŠUMPICH et al. 2011). Larvae develop in decaying wood and bracket fungi growing on deciduous trees.

\section{Triaxomera parasitella (HÜBNER, 1796)}

UTM: FD73, Nieznanowo reserve, comp. 488C: 1 female, 6 VI 2011, collected at light;

UTM: FD73, Starzyna reserve, comp. 698C: 1 female, ex larva, 9 V 2011, reared from Fomes fomentarius (L.) FR. on birch Betula pendula RoTH; 
UTM: FD83, Topiło, comp. 603A: 1 male, ex larva, 29 IV 2011, reared from Stereum rugosum PERS. on hazel Corylus avellana L., 2 females, ex larvae, 2 and 5 V 2011, reared from $F$. fomentarius on pedunculate oak Quercus robur L.;

UTM: FD85, Narewka, comp. 186D: 1 female, ex larva, 15 III 2013, reared from Fomitiporia robusta (P. KARST.) FIASSON \& NIEMELÄ on pedunculate oak Q. robur;

UTM: FD74, Lipiny, comp. 272D: 1 female, ex larva, 4 VI 2013, reared from the bark of sessile oak Quercus petraea (MATT.) LIEBL. infested with Bjerkandera adusta (WILLD.) P. KARST. and Hypoxylon fuscum (PERS.) FR.

The current distribution of Triaxomera parasitella covers almost the whole country (BUSZKO \& NOWACKI 2000), yet it is rather infrequently encountered. In BF it is known from old (BUSZKO 2001) as well as from more recent findings (ŠUMPICH et al. 2011). Larvae inhabit bracket fungi and rotting wood, presumably only of deciduous trees. The adults are sometimes attracted to light.

\section{Archinemapogon yildizae KoÇAK, 1981}

UTM: FD73, Starzyna reserve, comp. 698B, 698C and 730A: 1 female, 25 VII 2011, 1 female, 6 IX 2011, collected with barrier traps, 6 males, ex larvae, 29 IV-26 V 2011, reared from Fomes fomentarius (L.) FR. on birch Betula pendula Roth;

UTM: FD73, Starzyna, comp. 728A and 728D: 3 males and 4 females, ex larvae, 17 V-18 VI 2011, reared from Phellinus tremulae (Bondartsev) Bondartsev \& P.N. Borisov on aspen Populus tremula $\mathrm{L}$.;

UTM: FD73, Nieznanowo reserve, comp. 488C: 1 female, ex larva, 29 IV 2011, reared from Fomitopsis pinicola (Sw.) P. Karst. on Norway spruce Picea abies (L.) H. KARST, 1 male, ex larva, 26 VI 2011, reared from F. piniola on lime Tilia cordata Mill.;

UTM: FD83, Topiło, comp. 603A and 570D: 1 male, ex larva, 27 V 2011, 1 female, ex larva, 26 V 2011, reared from F. pinicola on black alder Alnus glutinosa GAERTN., 2 males and 2 females, ex larvae, 30 IV-15 VI 2012, reared from P. tremulae on aspen P. tremula, 1 male, ex larva, 24 V 2012, reared from Piptoporus betulinus (BULL.) P. KARST. on birch B. pendula;

UTM: FD73, Łozice, comp. 569D: 1 female, ex larva, 27 VI 2011, reared from $F$. fomentarius on birch B. pendula;

UTM: FD94, Wysokie Bagno reserve, comp. 477B: 2 males and 2 females, ex larvae, 17 IV-2 V 2012, reared from $F$. pinicola on Norway spruce P. abies, 1 male, ex larva, 21 IV 2012, reared from $F$. fomentarius on birch B. pendula;

UTM: FD85, Pogorzelce reserve, comp. 252B: 2 females, ex larvae, 17 IV and 17 VI 2012, reared from Pycnoporellus fulgens (FR.) DonK on Norway spruce P. abies, 2 males and 3 females, ex larvae, 23 IV-17 V 2012, reared from $F$. pinicola on lime $T$. cordata, 2 males and 2 females, ex larvae, 26 IV-8 VI 2012, reared from $F$. fomentarius on hornbeam $C$. betulus L., 3 males and 1 female, ex larvae, 17 IV-8 VI 2012, reared from Mensularia radiata (SOWERBY) LÁZARO IBIZA on hazel Corylus 
avellana L., 2 males and 2 females, ex larvae, 20-26 IV 2012, reared from Fomitopsis rosea (ALB. \& SCHWEIN.) P. KARST. on Norway spruce P. abies;

UTM: FD83, Podcerkwa reserve, comp. 577D: 1 male, ex larvae, 26 IV 2012, reared from $F$. fomentarius on birch B. pendula;

UTM: FD83, Podcerkwy, comp. 523C, 542D, 578B and 581D: 1 male, ex larva, 21 IV 2012, reared from $P$. tremulae on aspen $P$. tremula, 2 males and 2 females, ex larvae, 17 IV-2 V 2012, reared from M. radiata on hazel C. avellana, 2 males and 1 female, ex larvae, 21 IV-3 V 2012, reared from $F$. fomentarius on Norway maple Acer platanoides L., 6 males and 8 females, ex larvae, 30 IV22 VI 2012, reared from $F$. fomentarius on aspen $P$. tremula, 4 females, ex larvae, 24 V-10 VI 2012, reared from $F$. fomentarius on black alder A. glutinosa;

UTM: FD83, Lasy Naturalne Puszczy Białowieskiej reserve, comp. 547A: 1 female, ex larva, 12 V 2012, reared from $F$. pinicola on birch B. pendula;

UTM: FD95, Masiewo, comp. 67C: 14 males and 7 females, ex larvae, 28 I-29 III 2013, reared from $F$. fomentarius on black alder A. glutinosa, 7 males and 7 females, ex larvae, 1 II-5 IV 2013, reared from Bjerkandera adusta (WILLD.) P. KARST. on Norway maple A. platanoides;

UTM: FD95, Mikłaszewo, comp. 48A: 4 males and 8 females, ex larvae, 25 II-3 IV 2013, reared from $F$. pinicola on birch $B$. pendula;

UTM: FD85, Gruszki, comp. 80C: 3 males, ex larvae, 10 II 2013, reared from Mensularia radiata (SOWERBY) LÁZARO IBIZA on hazel C. avellana, 1 female, ex larva, 11 II 2013, reared from Laetiporus sulphureus (BULL.) MURRILL on black alder A. glutinosa;

UTM: FD85, Narewka, comp. 186D: 1 female, ex larva, 16 IV 2013, reared from B. adusta on hornbeam C. betulus, 3 males and 2 females, ex larvae, 29 I-15 IV 2013, reared from Phaeolus schweinitzii (Fr.) PAT. on Norway spruce P. abies;

UTM: FD74, Lipiny, comp. 272D: 2 males and 2 females, ex larvae, 11-26 VI 2013, reared from bark of sessile oak Quercus petraea (MATT.) LIEBL. infested with Bjerkandera adusta (WILLD.) P. KARST. and Hypoxylon fuscum (PERs.) Fr.

The species is at present known from the whole of Poland (BUSZKO \& NOWACKI 2000) including BF (BUSZKO 2001). It is one of the most commonly encountered species among saproxylic Tineidae. Larvae live gregariously in many species of wood-decaying fungi growing on both deciduous and coniferous trees. They often cause almost complete destruction of the sporocarp.

\section{Nemaxera betulinella (PAYKULL, 1785)}

UTM: FD83, Topiło, comp. 603A: 4 males and 4 females, ex larvae, 29 IV-9 VI 2011, reared from Cerrena unicolor (BULl.) MURRILl on birch Betula pendula RoTH;

UTM: FD73, Starzyna, comp. 728D: 1 male, ex larva, 17 VI 2011, 1 male, ex larva, 24 VI 2011, reared from Stereum sp. on aspen Populus tremula L.; 
UTM: FD83, Podcerkwy, comp. 578B: 1 female, ex larva, 12 V 2012, reared from Pseudochaete tabacina (SOWERBY) T. WAGNER \& M. FISCH. on hazel Corylus avellana L.;

UTM: FD73, Łozice, comp. 569D: 1 male, ex larva, 22 V 2012, 1 female, ex larva, 2 V 2012, reared from Bjerkandera adusta (WILLD.) P. KARST. on hornbeam Carpinus betulus L., 1 male, ex larva, 10 VI 2012, reared from Trichaptum biforme (FR.) RYVARDEN on birch B. pendula;

UTM: FD95, Masiewo, comp. 67C: 2 males and 2 females, ex larvae, 11 II-8 III 2013, reared from $B$. adusta on Norway maple Acer platanoides L.;

UTM: FD85, Narewka, comp. 186D, 1 male, ex larva, 6 II 2013, 1 female, ex larva, 14 III 2013, reared from $B$. adusta on hornbeam $C$. betulus;

UTM: FD85, Gruszki, comp. 80C: 4 females, ex larvae, 20 VI-3 VII 2013, reared from Stereum rugosum PeRs. on hazel C. avellana, 1 male and 3 females, ex larvae, 15 VI-9 VII 2013, reared from Fomitiporia punctata (PILÁT) MURRILl on hazel C. avellana.

This species occurs in a dozen localities scattered around Poland (BUSZKO \& NOWACKI 2000). Larvae inhabit a few species of wood-decomposing fungi, usually those growing on broadleaved species (BENGTSSON et al. 2008). Our findings of Nemaxera betulinella are the first records of the species in BF.

\section{Nemapogon granella (LINNAEUS, 1758)}

UTM: FD85, Gruszki, comp. 80C: 5 males and 2 females, ex larvae, 11 II-18 III 2013, reared from Laetiporus sulphureus (BULL.) MURRILl on black alder Alnus glutinosa GAERTN., 5 males and 4 females, ex larvae, 7 II-15 III 2013, reared from Hapalopilus croceus (PERS.) DONK on pedunculate oak Quercus robur L.;

UTM: FD85, Świnoroje, comp. 78: 1 male and 1 female, ex larvae, 3 and 20 VI 2013, reared from Phaeolus schweinitzii (Fr.) PAT. on Scots pine Pinus sylvestris L.

Nemapogon granella is one of the most common species in the family Tineidae and the present distribution of the species covers almost the whole of Poland (BUSZKO \& NOWACKI 2000). It occurs in both natural and anthropogenic environments (e.g. houses, barns), where it has become a serious pest of stored food products. In the wild the larvae inhabit sporocarps of wood-decaying fungi, preferably old and dry specimens.

\section{Nemapogon cloacella (HAWORTH, 1828)}

UTM: FD73, Nieznanowo reserve, comp. 488C: 1 male, 6 VI 2011, collected at light, 1 male and 1 female, 6 IX 2011, collected with barrier traps, 1 male, ex larva, 21 V 2011, reared from Fomitiporia punctata (PILÁT) MURRILl on hazel Corylus avellana L.;

UTM: FD85, Pogorzelce reserve, comp. 252B: 1 male, 21 V 2012, collected at light;

UTM: FD74, Sacharewo, comp. 413B: 4 males, 12 VI 2012, collected at light; 
UTM: FD73, Starzyna reserve, comp. 698C, 699B and 730A: 7 males and 4 females, 25 VII 2011, collected with barrier traps, 1 male, ex larva, 14 V 2011, reared from Ganoderma applanatum (Pers.) PAT. on pedunculate oak Quercus robur L., 1 male, ex larva, 19 V 2011, reared from Fomitiporia robusta (P. KARST.) FIASSON \& NIEMELÄ on pedunculate oak Q. robur;

UTM: FD83, Topiło, comp. 603A: 1 male and 1 female, ex larvae, 21 V 2011, reared fromFomes fomentarius (L.) FR. on birch Betula pendula RoTH;

UTM: FD73, Starzyna, comp. 728D: 1 male, ex larva, 16 V 2011, reared from Stereum sp. on aspen Populus tremula L.;

UTM: FD73, Łozice, comp. 569D: 3 males and 1 female, ex larvae, 6-10 V 2011, reared from Bjerkandera adusta (WILLD.) P. KARST. on hornbeam Carpinus betulus L.;

UTM: FD73, Topiło, comp. 600A: 1 male, ex larva, 5 IV 2012, reared from Mensularia radiata (SOWERBY) LÁZARO IBIZA on black alder Alnus glutinosa GAERTN.;

UTM: FD85, Gruszki, comp. 80C: 1 male and 2 females, ex larvae, 13 II-21 III 2013, reared from Porodaedalea pini (Brot.) Murrill [=Phellinus pini (Brot.) BondartSEV \& SingER] on Scots pine Pinus sylvestris L., 1 female, ex larva, 5 III 2013, reared from Laetiporus sulphureus (BULL.) MURRILL on black alder A. glutinosa, 3 males and 2 females, ex larvae, 11 II-27 III 2013, reared from Hapalopilus croceus (PERS.) DONK on pedunculate oak Q. robur;

UTM: FD85, Narewka, comp. 186D: 2 males, ex larvae, 8-26 II 2013, reared from B. adusta on hornbeam C. betulus, 1 male, ex larva, 7 II 2013, reared from Phaeolus schweinitzii (Fr.) PAT. on Norway spruce Picea abies (L.) H. KARST;

UTM: FD74, Lipiny, comp. 271C, 272C and 272D: 1 male, ex larva, $21 \mathrm{~V}$ 2013, reared from Heterobasidion parviporum NIEMELÄ \& KORHONEN on Norway spruce P. abies, 2 males, ex larvae, 19 V and 11 VI 2013, reared from the bark of sessile oak Quercus petraea (MATT.) LIEBL. infested with Bjerkandera adusta (WILlD.) P. KARST. and Hypoxylon fuscum (PERS.) Fr., 1 male, ex larva, 15 VI 2013, reared from B. adusta on hornbeam C. betulus;

UTM: FD94, Wysokie Bagno reserve, comp. 477B: 1 male, 3 VII 2013, collected at light.

This species is another common representative of the saproxylic tineids, yet unlike the previous species, it is found almost exclusively in natural environments. Larvae live in various wood-inhabiting fungi and in rotting wood. Adult moths are attracted to light.

\section{Nemapogon wolffiella KARSHOLT \& NIELSEN, 1976}

(Fig. 2)

UTM: FD83, Przewłoka reserve, comp. 670B: 1 male, 6 VI 2011, collected at light;

UTM: FD74, Sacharewo, comp. 413B: 1 male, 12 VI 2012, collected at light;

UTM: FD94, Wysokie Bagno reserve, comp. 477B: 1 male, 3 VII 2013, collected at light.

The species is known from only a few localities scattered across Poland (BUSZKO \& NOWACKI 2000). Recently it was recorded from south-eastern Poland (BĄKOWSKI \& 
LARSSON 2011) and from BF (ŠUMPICH et al. 2011). Little is known about the biology of this species. Like the larvae of other species in the genus, caterpillars of Nemapogon wolffiella develop in some species of wood-inhabiting fungi and rotting wood. Adult moths are sometimes attracted to light, and males are also lured to the sexual pheromones of some clearwing moths (Sesiidae) (BARKOWSKI \& LARSSON 2011, BENGTSSON et al. 2008)

\section{Nemapogon variatella (CLEMENS, 1859)}

UTM: FD83, Podcerkwa reserve, comp. 577D: 1 male, 22 V 2012, collected at light;

UTM: FD73, Starzyna reserve, comp. 698C: 1 male and 1 female, 25 VII 2011, collected with barrier traps;

UTM: FD85, Narewka, comp. 186D: 1 male and 2 females, ex larvae, 26 II-4 III 2013, reared from Phaeolus schweinitzii (FR.) PAT. on Norway spruce Picea abies (L.) H. KARST.;

UTM: FD74, Lipiny, comp. 271C and 272D: 1 female, ex larva, 19 V 2013, reared from the bark of sessile oak Quercus petraea (MATT.) LIEBL. infested with Bjerkandera adusta (WILLD.) P. KARST. and Hypoxylon fuscum (PERS.) FR., 1 male, ex larva, 9 VI 2013, reared from Fomitiporia robusta (P. KARST.) FIASSON \& NIEMELÄ on sessile oak $Q$. petraea, 3 males and 3 females, ex larvae, 5-15 VII 2013, reared from Stereum rugosum PERS. and B. adusta on hazel Corylus avellana L.

The species is widely distributed throughout Poland (BUSZKO \& NOWACKI 2000). The biology is similar to that of Nemapogon granella; larvae inhabit natural as well as anthropogenic environments and feed on various materials, including food products, grain, wood-decaying fungi and rotting wood.

\section{Nemapogon clematella (FABRICIUS, 1781)}

UTM: FD85, Gruszki, comp. 80C: 13 males and 23 females, ex larvae, 3 IV - 19 VII 2013, reared from decaying wood of hazel Corylus avellana L. covered with sporocarps of Hypoxylon fuscum (PERS.) FR.;

UTM: FD74, Lipiny, comp. 271C, 1 female, ex larva, 3 VII 2013, reared from decaying wood of hazel Corylus avellana L. covered with sporocarps of H. fuscum;

UTM: FD94, Wysokie Bagno reserve, comp. 477B: 1 female, 3 VII 2013, collected at light.

This species is known from several, partly historical, localities across the country (BUSZKO \& NOWACKI 2000). Larvae live in wood of deciduous trees decomposed by some wood-decaying fungi, e.g. Hazel Woodwart H. fuscum. The species is easy to find at this stage as larvae form characteristic protuberant galleries on the bark surface. These are composed of wood dust extruded by the caterpillars as they feed. The adults can often be reared in numbers from such material. 


\section{Nemapogon fungivorella (BENANDER, 1939)}

(Fig. 3)

UTM: FD85, Gruszki, comp. 80C: 3 females, ex larvae, 13 VI 2013, reared from Daedalea quercina (L.) PERS. on northern red oak Quercus rubra L.

The species is one of the most local tineids in Poland and has so far been recorded only in central and western parts of the country (BUSZKO \& NOWACKI 2000). Little is known about its biology but larvae are probably monophagous and feed exclusively on the fungus Daedalea quercina. They create galleries on the underside of the sporocarp resembling those of Montescardia tessulatellus. Records from fungi growing on beech Fagus sylvatica L. (ŚLIWIŃSKI 1963) require confirmation. This is a new species for the fauna of BF.

\section{Nemapogon picarella (CLERCK, 1759)}

UTM: FD73, Nieznanowo reserve, comp. 488C: 1 male, 6 VI 2011, collected at light;

UTM: FD85, Pogorzelce reserve, comp. 252B: 2 males, 21 V 2012, collected at light;

UTM: FD83, Podcerkwa reserve, comp. 577D: 2 males, 22 V 2012, collected at light.

The species is known from several localities in Poland (BUSZKO \& NOWACKI 2000). Larvae develop in sporocarps of wood-inhabiting fungi and in decaying wood of broadleaved trees. According to some authors it shows a preference for the fungus Piptoporus betulinus (BENGTSSON et al. 2008), while others indicate Inonotus radiatus (=Mensularia radiata) as the most preferred species (BUSZKO 1992).

\section{Tineinae}

\section{Elatobia fuliginosella (LIENIG \& ZELLER, 1846)}

(Fig. 4)

UTM: FD94, Wysokie Bagno reserve, comp. 477B: 1 female, 3 VII 2013, collected at light.

Until recently, this rare species had been recorded only from southern and southwestern Poland (BUSZKO \& NOWACKI 2000), but a recent record from central Poland (JAWORSKI et al. 2011) as well as the current finding in the BF suggest a wider distribution. The species is believed to be associated with open pine woods, where the larvae develop under the bark feeding on various kinds of detritus (BENGTSSON et al. 2008). Elatobia fuliginosella is recorded for the first time from the BF.

\section{Dryadaula caucasica (ZAGULAJEV, 1970)}

UTM: FD85, Pogorzelce reserve, comp. 252B: 1 male and 1 female, ex larvae, 6 IV 2012, reared from rotting wood of hornbeam Carpinus betulus L. infested with Stereum rugosum PERS.; 
UTM: FD74, Lipiny, comp. 272D: 1 male, ex larva, 9 VI 2013, 1 female, ex larva, 13 VI 2013, reared from the bark of sessile oak Quercus petraea (MATT.) LIEBL. infested with Bjerkandera adusta (WILlD.) P. KARST. and Hypoxylon fuscum (PERS.) Fr.;

UTM: FD94, Wysokie Bagno reserve, comp. 477B: 1 male, 3 VII 2013, collected at light.

This species was only recently recorded in Poland for the first time on the basis of specimens collected in BF (JAWORSKI et al. 2012) and currently no further records are known outside this area. Larvae live in wood-inhabiting fungi and rotting wood of deciduous species. The adults are sometimes attracted to light (present results). Our new records of Dryadaula caucasica in BF indicate a wide occurrence of this species in the area.

\section{Dryadaula irinae (SAVENKOV, 1989)}

(Fig. 5)

UTM: FD85, Gruszki, comp. 80C: 1 male, ex larva, 8 III 2013, 1 female, ex larva, 6 VI 2013, reared from dead branch of hazel Corylus avellana L. infested with fungus Hypoxylon fuscum (PERS.) FR.

Dryadaula irinae is a new species in the fauna of Poland. It was described under the name Archimeesia irinae from Latvia (SAVENKOV 1989). Subsequently, the species was reported only from Austria (HUEMER 1996) and Slovakia (PASTORÁLIS et al. 2011). Thus far, no information about its biology has been published and the results of our studies provide the first reliable data in this respect.

Three larvae of $D$. irinae were found during our studies and we succeeded in rearing the adult moths from two of them. The larvae have a reddish-brown body colouration and the head and tergal plates are almost black (Fig. 6). Aside from some sparse pale hairs on the head capsule and the sides of the body, they are almost naked. The larva produces a shelter of silk and frass on the surface of the substrate, under which it hides when not feeding (Fig.7). It is also under this cover that pupation takes place (Fig. 8). The larvae were found to feed on the stromata of Hazel Woodwart Hypoxylon fuscum growing on the bark of dead standing stems of hazel $C$. avellana (damaged stromata are shown in Fig. 7). The habitat was old-growth mixed forest with pedunculate oak Quercus robur L., Scots pine Pinus sylvestris L., and hornbeam Carpinus betulus L. as the main tree species. Along with the caterpillars of $D$. irinae, the material was also inhabited by the larvae of another saproxylic tineid Nemapogon clematella. 


\section{DISCUSSION}

Research on saproxylic insects in Poland has a relatively short tradition. Owing to the greatest diversity of species and relatively high degree of recognition, such research used to focus mainly on beetles. There has been practically no research of this type devoted to saproxylic moths, among which tineids are the largest group. Hence, knowledge about their biology and ecology is to be found in just a few literature sources (e.g. BUSZKO 1992, 1996, ŚLIWIŃSKI 1963, 1979).

As a result of three years of research in the Białowieża Forest, 20 species of saproxylic tineids (fungus moths) were recorded, which constitute over $80 \%$ of all saproxylic species within this family in Poland. Among those reported, one species, i.e. Dryadaula irinae, should be considered new to the Polish fauna. Moreover, a number of other tineid species rare both in Poland and in Europe were also recorded. This testifies to the great value of the area covered by the study. At the same time, several of the reported species belong to elements new to the Białowieża Forest; this demonstrates on the one hand the inadequate knowledge we have of this group of moths in this area, but on the other, the opportunities to discover further species, including taxa new to the Polish fauna.

A few of the species reported deserve special attention, especially as they are rare in Poland or Europe. A good example is Scardia boletella, a boreal-mountain element in the Polish fauna, with a small number of localities in the country, and at risk of extinction because of the conversion or loss of favourable habitats (BUSZKO 2004). A large number of observations of its presence in the Białowieża Forest (exit holes in wood, pupal cases protruding from bark, traces of larval feeding on the sporocarps of tree fungi) suggest that its conditions for survival in the area are good. Other rarely encountered tineids worth mentioning include Elatobia fuliginosella, Stenoptinea cyaneimarmorella and Dryadaula caucasica, species known from just a few localities scattered across Europe (HANNEMANN 1977, BENGTSSON et al. 2008, ROBINSON 2009). Their biology and ecological requirements, however, remain virtually unknown.

Equally interesting are the trophic associations of fungus moths. The development of some species, e.g. Archinemapogon yildizae, Nemapogon cloacella or Morophaga choragella, takes place on many taxa of arboreal fungi or in dead wood, without special preferences. A number of others, however, show a strong preference for fungal species. This is very evident in Agnathosia mendicella: the results of our studies as well as published data (KOMONEN et al. 2001, BENGTSSON et al. 2008) point to the association of this moth with the protected fungus, Fomitopsis rosea. Our studies also revealed the highly specialised food preferences in Nemapogon fungivorella, which was reared only from oak mazegill Daedalea quercina, or in Nemapogon clematella, which prefers wood infested by the fungus Hypoxylon fuscum. 
The results of our studies have provided insight into the biology of Dryadaula irinae, a species new to the Polish fauna. The species was described for the first time from Latvia (SAVENKOV 1989), and later only recorded on the basis of single specimens from Austria (HUEMER 1996) and, more recently, from Slovakia (PASTORÁLIS et al. 2011). A similar biology is probably characteristic of another member of the genus, D. caucasica. This species has recently been recorded for the first time in Poland, also on the basis of specimens collected in the Białowieża Forest (JAWORSKI et al. 2012).

\section{REFERENCES}

BĄKOWSKi M., LARSSON M. 2011. New record of Nemapogon wolffiella KARSHOLT et NiELSEN, 1976 (Lepidoptera: Tineidae) in Poland caught into a pheromone trap. Wiadomości Entomologiczne 30(3): 192.

BENGTSSON B.Å., JoHANSSON R., PALMQvist G. 2008. Nationalnyckeln till Sveriges flora och fauna. Fjärilar: Käkmalar - säckspinnare. Lepidoptera: Micropterigidae - Psychidae. ArtDatabanken, SLU, Uppsala.

BuJAKIEwICZ A. 2003. The Białowieża Forest - refuge for endangered macrofungi. Parki Narodowe i Rezerwaty Przyrody 22(3): 323-346. (in Polish)

Bujakiewicz A., Kujawa A. 2010. Macrofungi in selected reserves of Białowieża Forest. Parki Narodowe i Rezerwaty Przyrody 29(1): 3-26. (in Polish)

BUSZKO J. 1992. On the food preference in Nemapogon picarellus (CLERCK) and N. nigralbellus (ZELLER) (Lepidoptera, Tineidae). Wiadomości Entomologiczne 11(1): 61-62. (in Polish)

Buszko J. 1996. Tineid moths (Tineidae, Lepidoptera) inhabiting polyporous mushrooms and bird nests in Las Piwnicki reserve. Acta Universitatis Nicolai Copernici 96, Biologia 51: 49-55. (in Polish)

BuszKo J. 2001. Ordo (order) Lepidoptera - butterflies (scalewings). [in:] GuTOwSKI J.M., JAROSZEWICZ B. (eds.). Catalogue of the fauna of Białowieża Primeval Forest. Instytut Badawczy Leśnictwa, Warszawa: 248-268. (in Polish)

Buszko J. 2004. Scardia boletella (FABRicius, 1794). [in:] GŁOWACIŃSKi Z., NowACKi J. (eds.). Polish Red Book of Animals, Invertebrates. Instytut Ochrony Przyrody PAN, Akademia Rolnicza im. Augusta Cieszkowskiego, Kraków - Poznań: 228-229. (in Polish)

Buszko J., Nowacki J. 2000. Polish Entomological Monographs, Vol. 1. The Lepidoptera of Poland. A Distributional Checklist. Polish Entomological Society, Poznań - Torun.

Hannemann H.J. 1977. Die Tierwelt Deutschlands. 63. Teil. Kleinschmetterlinge oder Microlepidoptera III. Federmotten (Pterophoridae), Gespinstmotten (Yponomeutidae), Echte Motten (Tineidae). Fischer, Jena.

HUEMER P. 1996. Schmetterlinge (Lepidoptera) im Bereich der Naturschutzgebiete Bangser Ried und Matschels (Vorarlberg, Österreich): Diversität - Ökologie - Gefährdung. Vorarlberger Naturschau 2: 141-202. 
Index Fungorum 2013. www.indexfungorum.org [accessed on 01.07.2013]

JAWORSKi T., Hilszczański J., Plewa R. 2011. New records of saproxylic Tineidae and Oecophoridae (Lepidoptera) in Poland. Wiadomości Entomologiczne 30(4): 229-236. (in Polish)

JaWORSKi T., Plewa R., Hilszczański J. 2012. First report of Dryadaula caucasica (Zagulajev, 1970) from Central Europe and records of further rare tineids (Lepidoptera: Tineidae) in Białowieża Primeval Forest. Polish Journal of Entomology 81(1): 73-79.

Komonen A., Sittonen J., Mutanen M. 2001. Insects inhabiting two old-growth forest polypore species. Entomologica Fennica 12(1): 3-14.

PAstorális G., Kosorín F., LAŠTŮvkA A., LišKa J., Richter I., TOKÁR Z. 2011. Records of Microlepidoptera new to the fauna of Slovakia. Folia faunistica Slovaca 16(3): 143-150.

Robinson G. S. 2009. Biology, distribution and diversity of tineid moths. Southdene Sdn Bhd, Kuala Lumpur and Natural History Museum, London.

Savenkov N. 1989. A new species of genus Archimeesia [sic!] ZaG. (Lepidoptera, Tineidae) from Latvia. Latvijas Entomologs 32: 92-94.

SPEIGHT M.C.D. 1989. Saproxylic invertebrates and their conservation. Nature and Environment Series, No 42. Strasbourg: Council of Europe, Publications and Documents Division.

ŚLIWIŃSKI Z. 1963. New for Poland's fauna and rare Tineidae (Lepidoptera). Polskie Pismo Entomologiczne 33(8): 179-182. (in Polish)

ŚliwiŃSKi Z. 1979. New for Poland's fauna and rare Tineidae (Lepidoptera). Part II. Polskie Pismo Entomologiczne 49(4): 667-670. (in Polish)

ŠUMPICH J., LIŠKA J., DVOŔÁK I. 2011. Contribution to knowledge of the butterflies and moths (Lepidoptera) of north-eastern Poland with a description of a new tineid species from the genus Monopis HÜBNER, 1825. Polish Journal of Entomology 80(1): 83-116.

SzcZepkowski A., Kujawa A., KARASIŃski D., GierczyK B. 2011. The XVII Fungi Exposition of the Białowieża Forest in Hajnówka. Parki Narodowe i Rezerwaty Przyrody 30(3-4): 129-134. (in Polish)

Received: 10 September 2013

Accepted: 7 January 2014 